\title{
COMUNICACIÓN
}

\section{Occurrence of coccidiosis in canaries (Serinus canarius) being kept in private captivity in the state of Pernambuco, Brazil}

\author{
MANUELA F. L. DE FREITAS*, JAQUELINE B. DE OLIVEIRA*, \\ MIRIAM D. DE BRITO CAVALCANTI*, e DJALMA A. DE FREITAS**
}

\begin{abstract}
This study have an aim to outline the coproparasitological profile of canaries (Serinus canarius) belonging to a private captivity (Canaril Freitas) situated in state of Pernambuco, Brazil. From 327 analysed passerine birds, 167 (50,5\%) were parasitized by sporozoite of genre Isospora.
\end{abstract}

Key words: Serinus canarius, Bird coccidiosis, Protozoan, Isospora.

\section{INTRODUCTION}

In the Atlantic Ocean, situated a little further than 100 kilometres from the African coast, approximately on the same line of the Sahara Desert, it is situated the Arquipélago das Ilhas Canarias (Canary Island Archipelago). It was in the natural habitat where the first known canaries have come from ${ }^{1}$.

The strong and melodious singing of the canary as well as a diversity of colours makes the canary one of the most popular (passerine) birds in the world, blooming in the man the interest in its creation. Nowadays, the rearing of canaries has been evolving rapidly in the world and in Brazil. The Ornithological Federation of Brazil (Federação Ornitológica do Brazil - FOB) congregates various clubs in Brazil, and in the state of Pernambuco, the Ornithological Club of Pernambuco (Clube Ornitológico de Pernambuco - COPE) and the Ornithological Society of Garanhuns (Sociedade Ornitológica de Garanhuns - SOG) are the responsible for the incentive to the development of the local creation, promoting meetings, exhibitions and championships amongst the owners of canaries. The breeding of these birds in captivity is successful, but there are some points to consider, such as the manipulation of

the adult and babies birds; hygiene of the installations and utensils; adequate feeding; control of insects and rodents and infectcontagious illnesses.

Amongst the infect-contagious, the parasitic illnesses come out because they negatively interfere in the breeding of the birds. The coccidiosis, considered an important cause of enteritis and death in bird of all kinds, is an illness caused by protozoa of the group coccidia, family Eimeriidae. They are parasites intra-cell of the intestinal epithelium which cause alterations in the mucosa, provoking diarrhoea, sometimes, hemorrhagic and diminution of the absorption of nutrients ${ }^{2,3}$. The most common coccidia in birds are the ones from the genre Caryospora, Eimeria and Isospora ${ }^{2}$, being the latter the ones that submit, preferably, Passeriformes ${ }^{4}$.

\footnotetext{
* Parasitology Laboratory from the Biology Department of the Federal Rural University of Pernambuco. Rua Dom Manuel de Medeiros S/Nº, CEP - 52171-030, Recife-PE, manuelalfreitas@uol.com.br;

** Canaril Freitas, breder COPE n 210 e LK nº49. canarilfreitas@uol.com.br
} 
For many years, species of Isospora of passerine birds were classified on the basis of the oocysts structure and of the hosts in which oocysts were found, or called lsospora lacazei, after first species described from passerine birds ${ }^{5}$. Experimental infections of canaries (Serinus canarius) led to the discovery of two species of Isospora in these hosts with structurally similar oocysts, but with difference in the life cycle. Both species, I. serine and I. canaria, differ in the length of the prepatent and the oocysts excretion as well as the location the asexual and sexual stages of the protozoa ${ }^{6}$. No description of oocysts of Isospora of home canaries is found in the literate, but mentions have been made in relation to coccidiosis ${ }^{7}$. Therefore, this has as an aim to outline the parasitic profile of canaries belonging to a private captivity in the State of Pernambuco.

\section{MATERIALS AND METHODS}

327 S. canarius were analysed, kept in private captivity, Canaril Freitas, localized in the suburb of Paulista, state of Pernambuco, Brazil. The analysed birds in this captivity are from the light and dark lines, with and without factor (including the classical colours - blue and onyx), as well as stronger canaries such as the (Parisian Frill, Gloster, Norwich, Fiorino e Gibber). The passerine birds are reared in suspended cages, individually, or forming couples, or in collective bigger cages, being distributed according to their age as well and their classifications, colours or strengths.

In order to realize the copro-parasitological analyses, samples of justexcreted excretion were collected from various places of the trays of the cages, correctly laid with towel paper. The excretions were carefully put in collecting pot, having the date of collection, number of passerine birds and number of the cage, and sent in hypsothermic boxes containing ice to the Laboratory of Parasitology of Universidade Federal Rural de Pernambuco, where they were processed by the technique of spontaneous sedimentation. $^{8}$

\section{RESULTS AND DISCUSSION}

Out of the 327 birds, $167(50,5 \%)$ were parasitized by coccidian. Some oocysts found during the exams coproparasitological were sporulated, demonstrating in its interior two sporocyst containing four sporozoite each. This structure is a characteristic of the oocysts of the genre Isospora. As in this project, there was neither a measurement of the oocysts, nor their observation in electronic microscope, it was not possible to conclude the diagnoses to the species levels.

Two species of coccidian are described to canaries: The species $I$. canaria and I. serine, which had their life cycles largely studied through experimental infections of canaries ${ }^{6,9}$. The species I. serine presents a life cycle different to the other coccidian (which present an intestinal cycle only), because they have the ability to infect mononuclear cells which present a longer period of life in comparison to epithelial cells in the intestine, which makes the parasite able to survive and produce infecting forms for many months ${ }^{6}$. This charac-teristic of the $I$. serine of infecting these cells makes this parasite accumulate in the lungs, likely to return to the oral cavity via the bronchial tree, initiating further generations in the intestinal epithelium. On the other hand, the species I. canaria has a life cycle conventional of the coccidian, where all endogenous stages occur in the intestinal epithelium. The pre-patent period is 4 to 5 days for the I. canaria, and 9 to 10 days for the $I$. serine. The patency period lasts 11 to 13 days for infections by I. canaria, while the patent period is more chronic in infections by I. serine, remaining for more than 231 days ${ }^{6}$.

The presence of oocysts of Isospora in the samples of analysed excretion denotes that the coccidiosis is a very frequent parasitoid in the canaries, and it may be responsible for loss of weight, low reproduction and death inside a breeding group. It should be taken into account, however, the immunity which happens after the infection, having as a consequence the nonmanifestation of clinical signs, despite the elimination of oocysts in the excretion. Besides the clinical signs which denote the parasitism by Isospora $\mathrm{sp}$ in the intestine of canaries, the occurrence of respiratory clinical signs are also present, due to the multiplication of parasites in the lungs, in the case of infections by I. serine. This species is responsible for the longest permanence of the illness in a rearing of passerine birds. 


\section{RESUMEN}

Este estudio tiene como objetivo, caracterizar el estado coproparasitológico de los canarios (Serinus canarius) mantenidos en caitiverio en el estado de Pernambuco, Brasil. De 327 canarios examinados, 167 (50,5\%) presentaron infección por Isospora.

\section{REFERENCES}

1.- DUTRA A C. O canário através dos tempos. Ed: Nobel. São Paulo, SP. 1992; 320 pp.

2.- FOWLER M E. Zôo \& Wild Animal Medicine. Ed: W. R Saunders Co. Denver, Colorado. 1986. 1127 pp.

3.- URQUHART G M, ARMOUR J, DUCAN J L et al. Parasitología Veteterinaria. Ed: Guanabara koogan.
Rio de Janeiro, R J. 1987. 306 pp.

4.- BENEZ S M. Aves criação, clínica, teoria e prática. Ed: Robe. São Paulo, SP. 3 Ed. 2001. 522 pp.

5.- LABBÉ A. Sur les coccidies des oiseaux. In: Life cycles of two Isospora species in the canary, Serinus canarius Linnaeus. J Protozool 1977; 24: 57-67.

6.- BOX E D. Life cycles of two Isospora species in the canary, Serinus canarius Linnaeus. J Protozool 1977; 24: 57-67.

7.- WENYON C M. Protozoology. In: Box, E. D. Exogenous stages of Isospora serini (Aragão) and Isospora canaria sp. $\mathrm{n}$. in the canary (Serinus canarius Linnaeus). J Protozool 1975; 22: 165-9.

8.- GREVE J H. Parasitic Diseases. In: FOWLER M. E. Zoo \& Wild Animal Medicine. Ed. W B Saunders Company, Inc. 1986. p. 233-53.

9.- BOX E D. Exogenus stages of Isospora serini (Aragão) and Isospora canaria sp. $\mathrm{n}$. in the canary (Serinus canarius Linnaeus). J Protozool 1975; 22: 165-9.

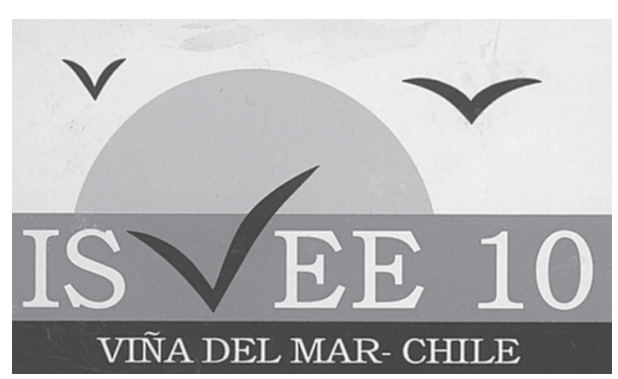

$10^{\circ}$ SIMPOSIUM INTERNACIONAL DE EPIDEMIOLOGÍA Y ECONOMÍA VETERINARIA

\section{$10^{\text {th }}$ INTERNATIONAL SYMPOSIUM FOR VETERINARY} EPIDEMIOLOGY AND ECONOMICS

17 - 21 de noviembre / november 17 - 21

Viña del Mar

CHILE 